\title{
Interactive effects of drought and pathogens in forest trees
}

\author{
Marie-Laure DeSPREZ-LoustaU ${ }^{a *}$, Benoit MARÇAIs $^{\mathrm{b}}$, Louis-Michel NAGELEISEN $^{\mathrm{c}}$, Dominique PIOU ${ }^{\mathrm{a}}$, \\ Andrea VANNINI ${ }^{\mathrm{d}}$

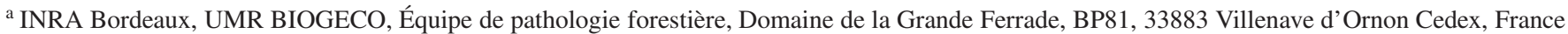 \\ ${ }^{\mathrm{b}}$ INRA Nancy, UMR IaM, Équipe de pathologie forestière, Champenoux, 54280 Seichamps, France \\ ${ }^{\text {c } M i n i s t e ̀ r e ~ d e ~ l ' A g r i c u l t u r e, ~ d e ~ l a ~ P e ̂ c h e, ~ e t ~ d e s ~ A f f a i r e s ~ R u r a l e s, ~ D e ́ p a r t e m e n t ~ S a n t e ́ ~ d e s ~ F o r e ̂ t s, ~ C h a m p e n o u x, ~} 54280$ Seichamps, France \\ ${ }^{\mathrm{d}}$ University of Tuscia, Department of Plant Protection, Via S. Camillo de Lellis, 01100 Viterbo, Italy
}

(Received 14 October 2005; accepted 28 April 2006)

\begin{abstract}
This review synthesizes the available knowledge on drought-disease interactions in forest trees with a focus on (1) evidence and patterns of drought-disease interactions, (2) current understanding of processes and mechanisms, and (3) three well documented cases studies. The first part is based on the analysis of a database of slightly more than one hundred studies, obtained by keyword searches combining drought, diseases or pathogens, and forest trees. A large majority of published studies referred to a positive association between drought and disease, i.e. disease favoured by drought or drought and disease acting synergistically on tree health status, with a predominance of canker/dieback diseases, caused by pathogens like Botryosphaeria, Sphaeropsis, Cytospora and Biscognauxia (Hypoxylon). The type of disease-related variables (incidence vs. severity) and the intensity and timing of water stress were shown to be significant factors affecting the drought- infection interaction. Interactions with other abiotic stresses and species-specific and genetic effects, related to host or pathogen, have also been reported. Direct effects of drought on pathogens are generally negative, although most fungal pathogens exhibit an important plasticity and can grow at water potentials well below the minimum for growth of their host plants. Studies on indirect effects of drought on pathogens through other community interactions are still relatively scarce. Positive drought-infection effects can mostly be explained by indirect effects of drought on host physiology. The predisposition and the multiple stress hypotheses are presented, as well as recent developments in the study of the molecular basis of abiotic and biotic stress, and their interactions. Sphaeropsis sapinea on pines, Biscognauxia mediterranea on oaks and root pathogens in declines associated with drought provide illustrative examples, treated as case studies, of pathogens of current significance associated with drought. The conclusion highlights some knowledge gaps, e.g. the role of latent parasites and the shift to a pathogenic stage, or the genetics of some fungal groups. The need for prevention of pathogen dispersal, especially crucial in the case of latent pathogens, is emphasized.
\end{abstract}

drought / water stress / pathogenic fungi / predisposition / forest trees

Résumé - Interactions entre sécheresse et agents pathogènes chez les arbres forestiers. Cette revue synthétise les connaissances actuelles sur les interactions entre sécheresse et maladies chez les arbres forestiers, avec trois grandes parties : (1) description des types d'interaction; (2) connaissances acquises sur les mécanismes impliqués ; (3) trois études de cas bien étudiées. La première partie est basée sur l'analyse d'une base de données d'une centaine d'études, sélectionnées par recherche sur mots clés. La plupart de ces études se rapportent à des maladies favorisées par la sécheresse ou à un effet synergique entre sécheresse et maladie sur l'état sanitaire des arbres, avec une prédominance de maladies à chancres ou de rameaux, causées par des espèces des genres Botryosphaeria, Sphaeropsis, Cytospora et Biscognauxia (Hypoxylon). Un effet significatif de l'intensité et de la durée du stress est montré dans certains cas sur le développement des maladies. Les effets de la sécheresse peuvent être différents selon qu'il s'agit de variables liées à l'incidence ou à la sévérité de la maladie. Des interactions avec d'autres stress abiotiques ou en relation avec des effets génétiques ou spécifiques ont également été décrits. Les effets directs de la sécheresse sur les pathogènes sont généralement négatifs, mais les champignons montrent une grande plasticité et peuvent généralement se développer à des potentiels hydriques inférieurs à ceux inhibant la croissance de leurs hôtes. Les effets positifs entre sécheresse et infection s'expliquent principalement par des effets indirects sur la physiologie des hôtes. Les hypothèses sur la prédisposition et les stress multiples sont présentées, ainsi que les développements récents sur les bases moléculaires des stress et de leurs interactions. Les trois études de cas concernent Sphaeropsis sapinea sur pins, Biscognauxia mediterranea sur chênes et l'interaction entre pathogènes racinaires et sécheresse dans les dépérissements. Dans la conclusion, quelques perspectives de recherche à privilégier sont mentionnées, comme le rôle et la biologie des parasites latents, ou la génétique de quelques groupes fongiques. Sur un plan pratique, la nécessité de limiter la dissémination des parasites, particulièrement cruciale dans le cas des parasites latents, est soulignée.

sécheresse / stress hydrique / champignons pathogènes / prédisposition / arbres forestiers

\section{INTRODUCTION}

Among a wide variety of abiotic and biotic factors, drought and pathogenic fungi are important stressors affecting forest and tree health. The separate effects of water deficits and

\footnotetext{
*Corresponding author: loustau@bordeaux.inra.fr
}

pathogens on tree physiology have been studied for decades. Interactions between drought and disease have also long been recognised $[47,84]$. Paradoxically, since moisture is indispensable for the germination and initiation of infection by fungal spores as well as for dispersal in many species [1], the effect of drought in enhancing fungal diseases of plants has frequently 
been reported, especially in forest trees [173]. This question has again moved to the forefront with the severe heat and drought wave of the summer 2003 in Europe and the concern is all the more important that such episodes might become more frequent in the future with global climate change [86].

The aim of this review is to synthesize the available knowledge on drought-disease interactions in forest trees with a focus on (1) evidence and patterns of drought-disease interactions, (2) current understanding of processes and mechanisms, and (3) three well documented cases studies.

\section{EVIDENCE AND PATTERNS OF DROUGHT-DISEASE INTERACTION}

Our synthesis was primarily based on the analysis of articles selected from the CAB database (1973-2005) by conducting keyword searches combining drought, diseases or pathogens, and forest trees. Our database included slightly more than one hundred studies dealing with specific cases of drought-disease interaction, which were categorised according to hosts, pathogens, and the methodology used to assess drought-disease interactions (Tab. I). All studies dealt with fungal pathogens (lato sensu, including Oomycetes) although bacteria pathogenic to forest trees have been studied in other woody hosts in interaction with water stress, e.g. Xylella fastidiosa [132]. The interaction was scored positive if disease was favoured in the drought (water deficit) treatment(s) or if drought and disease acted synergistically on tree health status. Not only statistically significant effects were considered but also correlative observations (epidemiological field observations). On the basis of the methodology used for the assessment of drought-disease interactions, the studies included in the database can be categorized in two main types. Most are experimental studies in which the development of disease caused by one specific pathogen in stressed host plants has been investigated. Most have used potted seedlings or saplings grown in greenhouse or nursery, subjected to experimental stress by various treatments of watering, and artificially inoculated, water stress being generally applied before and during interaction with the pathogen. The effect of drought (or water stress) has been assessed by comparing pathogen- or disease-related variables (extent of colonisation, lesion length) in water stressed inoculated plants to that in normally watered inoculated plants or by examining the relationship between symptom development and water potential. The variables used therefore commonly refer to severity of disease rather than incidence (frequency of infection). Few experimental investigations have been carried out so far including pathogen and abiotic stress with an ecophysiological approach $[10,128,129]$.

A second smaller group of references are epidemiological studies in which the effect of environmental factors, especially drought, on disease expression or the combined effects of drought and pathogens on tree health status, have been investigated in the field. The possible involvement of drought has been examined by studying spatial and temporal patterns of damage in relation to microclimatic or meteorological data, or water potential in trees. Simplest correlative analyses have associated outbreaks of several diseases to years with exceptionally hot and dry summers, e.g. Cryptostroma corticale on sycamore (Acer pseudoplatanus) [74] or site factors potentially conducive to water stress (shallow soils, texture) to severity of some diseases, e.g. Phomopsis alnea on black alder (Alnus glutinosa) [140] or Hypoxylon canker on trembling aspen (Populus tremuloides) [31]. Dendrochronological analyses have also been used to demonstrate the cooccurrence or sequential association of low precipitation periods, lower tree growth and invasion of bark or wood tissues by pathogens, such as Fusarium eumarti on oaks [166], Nectria on sycamore [77, 144], or Eutypa and Biscognauxia on beech (Fagus sylvatica) [83]. This approach has proved very interesting and useful in the case of complex decline syndromes where multiple abiotic (including drought) and biotic (pathogens and insects) factors are involved [80, 85, 106, 140].

\subsection{Disease types}

The foremost result of the literature analysis is that a great majority of published studies referred to a positive association between drought and disease. This applies both to broadleaved trees and conifers. A wide variety of hosts are represented (20 genera) but more than half of the studies dealt with Quercus, Populus (most often P. tremuloïdes), Pinus and Picea, which may reflect the productive and environmental importance of species in these groups in temperate regions. However, large differences both in the relative number of reports and in the frequency of "positive reports" (i.e. with a positive drought-disease interaction) were observed between pathogen guilds or disease types (Tab. I). It is remarkable that more than half of all studies focused on canker/dieback pathogens, with a large predominance of Botryosphaeria, Sphaeropsis, Cytospora, Biscognauxia and Entoleuca (Hypoxylon) species. Root diseases were also rather well represented. Conversely, very few studies with foliar diseases were found, and none about obligate parasites such as rusts and powdery mildews. The representativeness of the database for the general response of all diseases to drought interaction is therefore highly questionable. Actually, it can be assumed that most studies published in recent decades did not have the aim of testing the generality of a positive interaction between drought and pathogens, such as the Plant stress hypothesis, i.e. that abiotic stress increases the suitability of plants as food for herbivores, often referred to by entomologists [103]. Rather, experimental studies mostly focused on some pathogens for which circumstantial evidence linking drought and disease in natural conditions had previously been reported, with the aim to bring experimental support and some insights to our understanding of the processes involved $[173,175]$. The over representation in the database of diseases having a strong positive link with drought is further supported by the fact that the more a group is represented the more consistent is its response to drought, i.e. with a high frequency of "positive reports". Thus, when comparing canker and foliar diseases, both their respective number of reports and frequency of "positive" reports are likely to be indications of stronger or more frequent 
Table I. Classification of published studies on drought-disease interactions in forest trees.

\begin{tabular}{|c|c|c|}
\hline & Total & $\begin{array}{l}\text { Positive drought-disease } \\
\text { interaction* }\end{array}$ \\
\hline \multicolumn{3}{|l|}{ Hosts } \\
\hline Broadleaved trees & 82 & $56(68 \%)$ \\
\hline Quercus & 32 & $22(63 \%)$ \\
\hline Populus & 14 & 22 \\
\hline Conifers & 35 & 10 \\
\hline Pinus & 22 & \\
\hline Picea & 10 & \\
\hline Diseases & 117 & $78(67 \%)$ \\
\hline Anthracnoses (Discula, Apiognomonia, Septoria) & 7 & $3(43 \%)$ \\
\hline Beetle-associated Ophiostomatoïds & 6 & $1(17 \%)$ \\
\hline Cankers / shoot blights, including: & 64 & $53(83 \%)$ \\
\hline Botryosphaeria & 12 & \\
\hline Sphaeropsis sapinea & 10 & \\
\hline Cytospora & 9 & \\
\hline Hypoxylon / Biscognauxia & 13 & \\
\hline Foliar & 5 & $2(40 \%)$ \\
\hline Phytophthora root rot and stem cankers & 14 & $7(50 \%)$ \\
\hline Root pathogens (Armillaria, Heterobasidion, others) & 18 & $10(56 \%)$ \\
\hline Vascular & 3 & $2(67 \%)$ \\
\hline \multicolumn{3}{|l|}{ Methodological approach $^{+}$} \\
\hline Experimental studies on potted seedlings or with excised tissues & 70 & $53(76 \%)$ \\
\hline Experimental studies in the field & 9 & $5(56 \%)$ \\
\hline Epidemiological studies in the field & 32 & $25(78 \%)$ \\
\hline
\end{tabular}

* Disease favoured by drought or drought and disease effects acting synergistically on tree health; non-positive records include no effect, or negative or mixed effects.

${ }^{+}$For hosts and diseases, each specific interaction was considered individually, whereas the methodological approach may apply to several pathogens.

positive drought-disease interaction for the former than for the latter. Data from the French Department of Forest Health after the drought wave of 2003 are consistent with this differential response, although many factors might explain temporal patterns. Reports of poplar rusts showed a marked decrease in 2003 whereas those of Sphaeropsis sapinea showed a marked increase in 2003-2004, especially for the second year (relative to the total number of disease reports). $S$. sapinea on pines, as well as Biscognauxia mediterranea on oaks, are illustrative examples of canker/dieback pathogens with only positive interactions with drought reported. They will be presented below in more detail, as case studies. A few reports, however, demonstrated a negative effect of drought on some canker diseases, such as Thyronectria canker of honeylocust (Gleditsia triacanthos) [87] and Cryphonectria cubensis on Eucalyptus [192]. Contrary to most canker diseases, mixed results on droughtdisease interaction are often reported in foliar and root diseases, even for the same etiological agent, as exemplified by anthracnoses and Phytophthora diseases (see below).

\subsection{Disease- or health status-related variables}

In a few cases where different types of disease-related variables were studied, contrasting results were obtained for the effects of drought on the incidence of disease (related to the frequency of infection) and on the severity and impact of dis- ease (related to symptom development and effects on trees), with less positive or negative effects for the former as compared to positive effects for the latter [23, 73]. Anthracnose and Phytophthora diseases are typical and well documented examples. Contrasting observations on the influence of climatological factors on dogwood (Cornus florida and C. nuttallii) anthracnose caused by Discula destructiva have been reported [55]. In a study with dogwood seedlings exposed to natural inoculum, Britton [30] clearly established that both primary infection, at the initiation of epidemics, and secondary cycles, were related to rainfall. This was consistent with higher severity of the disease under moist conditions in some areas [46]. However, rainfall also promotes host vigour and has been reported to lessen disease impact [55]. Moreover, experimental studies demonstrated a predisposition to the disease by drought stress, in agreement with some field observations $[55,67,76]$. A further reason for mixed responses to drought in anthracnose diseases is that different organs are affected. Differential effects of a water stress treatment were demonstrated on London plane (Platanus acerifolia) cuttings when leaf or twig symptoms were considered, with a negative effect for the former and a positive for the latter [188]. The same was observed for Septoria musiva [130].

Although Phytophthora diseases such as those caused by $P$. cinnamomi are generally recognised to be more frequent on soils with impeded drainage favourable to the pathogen [49, 65], severe losses have also been reported on well drained 
soils or even dry areas $[28,148]$. Negative effects of drought on the development of $P$. cinnamomi in soil or in bark have often been reported $[32,116,125,195]$ whereas synergistic interactions between drought and infection have been demonstrated on tree physiology and the severity of disease symptoms $[20,128,129]$.

\subsection{Intensity and timing of water stress}

In most reports, experimental stress was tested at only one level (stressed/non stressed), often with extreme values in studies with potted plants. The influence of stress intensity on plant response to infection may explain contrasting results obtained in different studies, especially between greenhouse and field studies [107]. In addition, non-linear responses were usually found in the few studies where a range of stress intensities or water potentials were used $[51,61,118]$. In most cases, a trend of increasing disease severity with increasing water stress was observed, either with a rather continuous pattern or with threshold levels. Schoeneweiss [176] summarised the different patterns of relationship between water stress and disease, which he linked to pathogen aggressiveness. According to this scheme, threshold levels of water stress ("critical water deficits") are required for predisposition to non-aggressive pathogens, but as pathogen aggressiveness increases, the influence of threshold levels of stress becomes less evident and the favourable influence of water stress overall decreases. An example of a nonaggressive canker fungus is provided by Botryosphaeria dothidea which is able to develop in stems of various host species only after plant water potentials have reached lower values than the threshold level of -1.2 to $-1.3 \mathrm{Mpa}$, with colonisation extent increasing with decreasing water potential [51]. However, levels of water stress required for the development of Sphaerospsis sapinea in pines showed a large variation between studies (cf. below). Referring to Schoeneweiss' classification, Ragazzi et al. [165] qualified Diplodia mutila of medium aggressiveness since canker development was not nil in non-stressed seedlings but increased with water stress. Cytospora chrysosperma on aspen [81] or Botryosphaeria dothidea on pistachio [117] are other examples.

In some cases, non monotonic relationships between water deficit and disease were shown, with an optimum at intermediate values. Lindberg and Johansson [111] clearly demonstrated such a pattern for Heterobasiodion annosum in Picea abies, with high host resistance at potentials higher than $-0.5 \mathrm{MPa}$, low resistance between -0.5 to $-1.5 \mathrm{MPa}$, and increasing resistance below $-1.5 \mathrm{MPa}$. Attenuation of the activity of decay fungi by both high and low moisture contents of wood, in dead timber as well as in living trees, is a long established fact [167]. Wood moisture was also shown to be an important factor determining the success of infection of Sitka spruce (Picea sitka) stumps by Heterobasidion annosum, with an optimum at $30-70 \%$ saturation $[16,168]$.

Duration and timing of stress were also shown to have an influence on the outcome of host-pathogen interactions. In predisposition studies with $B$. dothidea, a minimum duration of
3 days at the threshold level was required after inoculation; on the other hand, tissues could recover resistance 3-5 days after the stress was relieved [51]. Johnson et al. [89], working with Sphaeropsis sapinea on Scots pines ( $P$. sylvestris), demonstrated that saplings subjected to stress levels of -3 to $-4.5 \mathrm{MPa}$ were able to confine canker expansion when watering was resumed within a few days after inoculation whereas increased canker development occurred when water was not limiting before inoculation but withheld during 2 or 3 weeks after inoculation. Differential effects of water stress in relation to timing before or after infection have also been reported for Lasiodiplodia theobromae on dogwood, with a more important effect of pre-inoculation than post-inoculation stress on canker development [142], a typical pattern of predisposition. A heavy watering prior to inoculation associated with water stress after infection increased Dutch elm disease [183]. For $P$. cinnamomi on red oak (Quercus rubra), an increase in lesion length was observed after but not during a period of stress [125]. The favourable effect on disease of alternating wet and dry periods is consistent with field observations. In Australia, dieback epidemics associated with P. cinnamomi in eucalypt (Eucalyptus marginata) forests were related to typical weather sequences including three or four months of heavy rainfall followed by three or four months of low rainfall [127].

\subsection{Drought and other abiotic stresses}

Comparisons or interactions of drought with other environmental stresses have been investigated in a few studies. Freezing stress in dormant plants, defoliation, and nutrient stress have often been shown to have predisposition effects comparable to water stress for canker diseases, such as those caused by Entoleuca (Hypoxylon) and Cytospora in aspen [12,81], Godronia and Botryosphaeria in Betula spp. [51,60]. In black spruce (Picea mariana) seedlings, predisposition to Botrytis cinerea was obtained either by drought or heat and dark [221]. Heat induced susceptibility has been reported in other cases [173].

Erbaugh et al. [67] demonstrated that drought and light stresses interacted on predisposition to dogwood anthracnose: no effect of drought on disease severity was observed in unshaded trees (100\% light) whereas drought increased severity on all shaded trees, with a maximum disease progression increase at $50 \%$ light but the highest overall disease level at $10 \%$ light in droughted trees.

\subsection{Species-specific and genetic effects}

Mortality patterns following severe drought have often been shown to be species specific, resulting in shifts in species composition of stands after severe disturbance [46, 204]. A clonal pattern was even shown for aspen decline [72]. Differential responses of tree species or genotypes to water deficit and pathogens may explain such patterns [164]. In a study of the influence of the intense 1985-1988 drought on tree mortality in the southern Appalachian mixed-Quercus species forest, 
Clinton et al. [45] found scarlet oak ( $Q$. coccinea) to be the most frequently dead or declining species, in agreement with previous reports showing a primary link to drought-induced outbreak of Armillaria mellea. The analysis of the oak decline which occurred in France following the severe 1976 drought showed that only Quercus robur was affected [14]. This could be explained by a higher sensitivity of $Q$. robur than $Q$. petraea to water deficits and a higher susceptibility to root pathogens [109, 161,205].

Genetic variation in either pathogen or host has been shown to be a source of variation in the response of trees to drought and infection in some studies. In the sycamore (Platanus occidentalis) canker caused by Lasiodiplodia (Botryodiplodia) theobromae, water stress had its greatest effects on increased canker development by the less virulent strain [110], in agreement with the scheme proposed by Schoeneweiss [176]. In contrast, Blodgett et al. [23,24] studying Sphaeropsis sapinea on red pine (Pinus resinosa), reported significant effects of drought in increasing disease development only for the more aggressive A morphotype. The same trend was observed with Cytospora on willow (Salix spp.) [100].

Interaction effects of drought and genetic disease resistance of the host have been mostly investigated for woody ornamentals. Blaker and MacDonald [20] demonstrated that moderate water stress predisposed normally resistant rhododendrons to severe root and crown rot caused by Phytophthora cinnamomi. A similar tendency was observed for Lasiodiplodia theobromae on dogwood, with the least susceptible cultivar in the absence of stress being the one with largest cankers after waterstress prediposition [142].

\section{PROCESSES AND MECHANISMS}

Theoretically, three main types of drought-disease interaction can be expected:

- A direct effect of drought on pathogens;

- Indirect effects of drought on pathogens through other community interactions;

- Interaction effects through host physiology; here, two types of interactions can be distinguished: (1) an effect of drought on tree susceptibility to disease: the predisposition concept; or (2) combined effects of infection and drought on tree physiology: the multiple stress concept.

\subsection{Direct effects of drought on pathogens}

As mentioned earlier, direct effects on pathogens, which affect primarily the free stages of fungi, i.e. spores and infective forms, are expected to be mainly negative, since most fungi require free water or high moisture for spore dispersal, germination and infection [105]. Even for diseases showing a close positive relationship with drought such as those caused by $\mathrm{Hy}$ poxylon (Biscognauxia) or by Sphaeropsis sapinea, the production and activity of primary inoculum (ejection and germination of ascospores) is associated with high precipitation or high relative humidity $[191,203]$. These direct negative effects are likely to be decisive, in a given season, for polycyclic diseases with many repeated cycles including such processes. Many foliar diseases, such as rusts, fall under this category, possibly explaining their low level of occurrence in the database, because of the negative interaction of drought and disease in these cases. The same negative effect may be expected for fine root pathogens such as Phytophthoras for which dispersal relies on flagellate zoospores swimming in free water and therefore requires that the spaces between the soil particles are filled with water $[64,127]$.

Water content may also have a direct effect on fungal growth within the host. Many authors have investigated the response of mycelial growth or sporulation to water potentials in vivo or in vitro $[63,66,79]$. As a general rule, most fungal pathogens exhibit an important plasticity and can grow at water potentials well below the minimum for growth of most higher plants: many species can sustain significant growth (more than $50 \%$ of optimal) at water potentials as low as -2 MPa ([49], Tab. II). Botryosphaeria dothidea exhibited a remarkable tolerance to low water potentials, even for germination and germ tube elongation [117]. Badisiomycetes and zoosporic organisms, such as Phytophthoras, are generally less tolerant of low water potentials than ascomycetes [25,63].

\subsection{Indirect effects through community interactions}

Drought could impact the epidemiology of pathogens through effects on other organisms within the community. This is particularly relevant for insect-vectored diseases such as bark beetle-Ophiostomatoïd fungi $[101,171]$ and Dutch elm disease. Gibbs and Greig [75] reported a high invasion success of the large elm bark beetle in elms during the exceptionally hot, dry summer of 1976 in England. However, the overall course of the epidemic was slightly affected since the higher insect establishment was counterbalanced by a lower transfer of the fungus from beetle to elm and slower subsequent development of the fungus within the tree.

Other indirect effects of drought may occur through mutualistic or competing species of the pathogenic fungus. The literature in this field is relatively scarce. Malajczuk and Theodorou [121] suggested that the prevention of sporangium formation in $P$. cinnamomi at water potentials around $-1 \mathrm{MPa}$ might be due to direct effects on stimulatory bacteria rather than on the pathogen itself. In contrast, the colonisation of pine stumps by Heterobasidion annosum might be favoured during drought episodes due to lower antagonism by Phlebiopsis gigantea [169]. Klepzig et al. [102] showed that the growth of the three major fungal associates of the southern pine beetle is strongly affected by decreasing water potential, in favour of mycangial fungi and bark beetle success.

\subsection{Interaction effects through host predisposition to disease by drought}

After the pioneer work by Bier [18, 19] on the relationship between bark moisture and development of fungi, the 
Table II. Direct effects of water potential on growth of some forest pathogens.

\begin{tabular}{|c|c|c|c|c|}
\hline & $\begin{array}{l}\text { Water potential } \\
\text { control }\end{array}$ & $\begin{array}{l}\text { Optimal water } \\
\text { potential (Mpa) }\end{array}$ & $\begin{array}{l}\text { Water potential at } \\
\text { growth reduced by } 50 \%\end{array}$ & Reference \\
\hline Botryosphaeria dothidea & $\mathrm{O}^{*}$ & -2 & -5 & {$[116]$} \\
\hline Cryphonectria cubensis & $\mathrm{O}$ & 0 & -2.6 & [190] \\
\hline Cryphonectria parasitica & $\mathrm{O}$ & -1 & -4 & {$[72]$} \\
\hline Cytospora chrysosperma & $\mathrm{M}, \mathrm{O}$ & -1 & $<-1.8$ & {$[80]$} \\
\hline Cytospora kunzei & & -1.4 to -1.5 & & Profer (cited in [80]) \\
\hline Diplodia mutila & $\mathrm{O}$ & -0.35 to -1.75 & -3 & {$[164]$} \\
\hline Phytophthora cinnamomi & $\begin{array}{l}\mathrm{O} \\
\mathrm{M} \\
\text { In vivo }\end{array}$ & $\begin{array}{l}-0.5 \text { to }-1.5 \\
>-0.5\end{array}$ & $\begin{array}{l}-2 \text { to }-3 \\
-1 \text { to }-2\end{array}$ & $\begin{array}{l}{[48]} \\
{[120]}\end{array}$ \\
\hline Thyronectria austro-americana & M & -0.4 & $<-4.5$ & {$[86]$} \\
\hline $\begin{array}{l}\text { Exidia glandulosa } \\
\text { Stereum gausapatum } \\
\text { Vuilleminia comedens }\end{array}$ & $\mathrm{O}$ & $\begin{array}{l}-0.2 \\
-0.2 \\
-0.4\end{array}$ & $\begin{array}{l}-0.8 \\
-2.1 \\
-1.2\end{array}$ & {$[25]$} \\
\hline
\end{tabular}

* $\mathrm{M}=$ matric, $\mathrm{O}=$ osmotic.

concept of plant predisposition to disease by environmental stress was developed by Schoeneweiss [173-176] who initiated experimental research on predisposition in woody plants under controlled conditions with fine monitoring of plant water status. An important observation is that pathogens that cause increased damage in plants predisposed by stress are usually already present on or in their host before stress, as saprophytes or endophytes (see case studies). Schematically, two main groups of mechanisms may explain predisposition: (1) water stressed tissues being a better substrate for growth of pathogens and (2) a decrease in active disease resistance. A review of biochemical and biophysical aspects of water deficits and the predisposition to disease in plants was completed by Boyer [27].

It is well established that carbohydrate and protein metabolisms are very sensitive to changes in plant water status. Changes in tree chemistry may then provide compounds that stimulate metabolism and growth of pathogens or decrease toxic or inhibitory contents [210]. For example, glucose, which increases in stressed trees, stimulates growth of Armillaria and enables it to grow in the presence of inhibitory phenols [210]. Popoola and Fox [162] also demonstrated that levels of carbohydrates, fatty acids and amino-acids were altered in stressed Lawson cypress plants as compared to controls, favouring increased growth of Armillaria mellea and A. gallica on root extracts. Similarly, certain amino-acids, e.g. proline, asparagine, alanine known to stimulate hyphal growth of Entoleuca (Hypoxylon) mammata were found in increased concentrations in water-stressed plantlets of Populus tremuloïdes [15].

Besides drought effects through the nutritional requirements of pathogens in stressed host tissues, changes may affect active resistance mechanisms in trees. The suppression of such mechanisms, e.g. host enzymes with a lytic action on fungal hyphae, in stressed plants has been supported by various observations. McPartland and Schoeneweiss [135] found that Botryosphaeria dothidea hyphae in vessels of unstressed resis- tant stems of birch (Betula alba) were thin and contorted compared to relatively large and rectilinear hyphae in vessels of stressed stems. The production of antimicrobial compounds, such as phytoalexins, has been shown to be affected by tree water status [104]. Cupressotropolones produced in cypress when challenged by Diplodia pinea f. sp. cupressi and inhibiting its development, were found to accumulate more slowly and at lower concentrations in water stressed plants as compared to controls [119]. The process of formation of the necrophylactic periderm, an active defense barrier against pathogen colonisation, was shown to be delayed in water stressed tissues [163]. Consistent with these findings, is the longer window of wound susceptibility to canker pathogens in stressed trees than in well-watered trees [133] and patterns of callusing in various hosts in response to infection and water stress $[7,17]$.

\subsection{Interaction effects: drought and infection acting as multiple stresses}

The general conceptual framework of the response of organisms to stress, first developed for humans by the pioneer in stress research Hans Selye, may be applied to plants [108]. According to this scheme, the response to stress (GAS = general adaptation syndrome) involves three phases: the alarm reaction, the resistance stage, and following long term exposure to the stressors or in case of a severe stress, exhaustion. Since both infection and drought act as stressors, each reducing the plant's capacity for plastic response, it is likely that their combined occurrence has additive deleterious effects and may lead more rapidly to exhaustion [10]. Paul and Ayres [154, 155] provided a nice illustrative example in a series of experiments with groundsel rust, showing that mechanisms of compensation for infection (principally higher leaf-to-root ratio) were much less effective during drought than in well-watered plants and even an aggravating factor of water stress. Mechanisms 
producing a synergistic effect between water deficit and infection in trees have been described in a study of Dutch elm disease (DED) in Ulmus minor [183]. Vessel cavitation is considered a determinant process leading to wilting, induced either by water stress or DED. The severity of symptoms after inoculation associated with water stress was increased in plants with large vessels more prone to cavitation.

The tree decline concept was developed by Manion [123, 124] to address complex decline syndroms involving a variety of etiological agents, including biotic and abiotic factors. The concept is illustrated by a decline spiral constituted of three tiered inward rings, corresponding to the predisposing, inciting, and contributing stressing factors, respectively. Decline is induced by the sequential occurrence of one stressing factor from each ring, factors within each ring being interchangeable. This spiral model has been widely used to analyse a number of decline situations. Drought has very often been considered as an inciting factor and root pathogens, such as Armillaria, as contributing factors $[72,145,146]$. The role of pathogens as predisposing or triggering agents of decline diseases has also been recognised, especially powdery mildew and Phytophthora spp. in oak declines ([57,210], cf. case study).

\subsection{Molecular basis of drought-infection interactions}

The study of plant responses to stress at the molecular level has advanced considerably in recent years. Signalling pathways and genes involved in resistance to pathogens have been unravelled, first in model plants [54, 208] and increasingly in many other species, including trees $[9,68,141]$. The molecular basis of plant response to abiotic stresses has also been extensively studied $[213,219,224]$. A number of studies provide some evidence of common mechanisms in response to a variety of stresses [108]. For example, Nagy et al. [147] demonstrated that drought stress in Norway spruce (Picea abies) seedlings induced some defenses similar to those of pathogen infection, i.e. chitinases. A pine chitinase gene and the chestnut cystatin expression were shown to be induced by fungal infection as well as abiotic stress $[112,157]$. Increasing evidence suggests that signalling pathways mobilized for different stresses may share common components, such as ABA or mitogen activated protein kinase MAPK [136, 222]. The functional overlap between the signalling networks activated by different stresses may explain the cross-protection or crosstolerance phenomena, in which a particular stress can induce resistance to a subsequent different stress [26, 198], including drought and pathogen [40]. This may explain why mildly stressed plants can be more resistant to pathogens [88]. However, other studies strongly suggest that the same gene may inversely modulate disease resistance and abiotic stress tolerance [220]. Moreover, recent studies involving a combination of different stresses, e.g. drought and heat, revealed a complex and specific pattern of plant response, including only a part of the responses to single stresses and transcripts specifically expressed in the combined stress condition [170].

The potential effects of stress on the genetics of pathogenic agents represent a new area of research, with recent results es- pecially for viral and bacterial human diseases. Pseudomonas aeruginosa is a ubiquitous environmental bacterium, capable of infecting a wide variety of organisms, from plants to animals and humans, as an opportunistic pathogen. Virulence genes were shown to be expressed not in a constitutive way but only when the bacterial population reached a critical density allowing it to overwhelm host defenses and to establish infection [8]. Another type of host stress - pathogen virulence interaction involving oxidative stress has been described by Beck and collaborators [13]. Variants of several viruses with increased virulence were shown to occur in hosts (humans and experimental mice) subjected to antioxidant vitamin deficiencies. Such phenomena might be explained by oxidative stress inducing faster viral replication and higher viral mutation rate. The formation of reactive oxygen species leading to oxidative stress is also a common response in plants, following exposure to biotic or abiotic stresses $[6,143]$.

\section{CASE STUDIES}

\subsection{Sphaeropsis sapinea-Pinus}

Sphaeropsis sapinea (Fr.) Dyko \& Sutton (syn. Diplodia pinea (Desm.) Kikx.) is one of the most important parasites of pines, distributed worldwide and causing a great variety of symptoms: shoot blight, branch and stem canker, tip dieback, cone infections, blue stain and root disease, often killing trees. $S$. sapinea has also been reported in other conifers (Abies, Cedrus, Larix, Pseudotsuga...) but with lesser damage than in pines. The first description of the fungus was made by Fries in 1822 in Scandinavia and subsequent mentions in the XIXth century are from Europe and Eastern USA. However, disease outbreaks associated with $S$. sapinea were first reported from exotic pine plantations in the 1910s in South Africa [190,212]. Disease losses associated with $S$. sapinea have now been reported from all pine plantation areas in the Southern Hemisphere, e.g. New Zealand, Chile and Australia [56], and in the Northern Hemisphere, e.g. Northeast of the USA [158], East of China [178] and Europe [71,97, 160]. In most of these regions, an increasing number of reports has been issued during the last decades. The main affected species are $P$. radiata, $P$. pinaster and $P$. patula in the Southern Hemisphere, $P$. nigra and $P$. sylvestris in Europe and $P$. sylvestris, $P$. resinosa and $P$. nigra in the USA. It is striking that the same species may be little affected in its natural area, and suffer severe damage in exotic plantations, e.g. $P$. radiata, $P$. pinaster and $P$. sylvestris. S. sapinea is generally recognised to undergo only asexual reproduction [189]. However, a significant variation in morphology and cultural characteristics has been described between isolates [99]. Two forms (I and II) were distinguished in France [139] and two morphotypes (A and $\mathrm{B}$, roughly corresponding to II and I, respectively) in the USA $[151,186,209]$. A third morphotype (C) was recently described [214]. Using multiple gene genealogies, de Wet et al. [215] demonstrated that all isolates representing the $\mathrm{A}$ and $\mathrm{C}$ morphotypes were grouped in separate but closely related clades, in contrast to isolates of the $\mathrm{B}$ morphotype 
which grouped together in a different clade and were therefore described as the new species Diplodia scrobiculata. The A morphotype seems to be dominant in all areas where disease has been reported. Pathogenic tests generally demonstrated a higher virulence for A and C than for B [21-24, 214]. Several studies with vegetative compatibility groups and molecular markers showed a high genetic variability of $S$. sapinea morphotype A in some areas, e.g. South Africa [33,181]. A recent study using SSR markers, however, revealed an overall low diversity and no geographic differentiation at a regional and even world scale [34]. S. sapinea can penetrate host tissues either directly in buds, current shoots and needles or through wounds $[41,44,120,151,158]$. It has recently been shown to occur as a latent pathogen in healthy pine tissues, especially in shoots and cones [69, 70, 182, 185]. Field observations and experiments have usually associated the incidence and severity of disease with various stress factors (nutrition, hail, drought...) which would trigger host susceptibility $[98,149,184,190]$. Effects of water stress on the Pinus-S. sapinea interaction have been investigated in several experimental studies, with wound inoculations on stems or shoots of young saplings. A greater development of symptoms was consistently associated with water stress [11, 23, 24, 152]. Moderate water stress (minimum predawn leaf potentials of -1.5 to $-2 \mathrm{MPa}$ ) was shown to be effective in increasing symptom severity, e.g. inducing a two-fold increase in canker length, in various pine species $[11,23,24,43]$. Lower levels of stress $(\psi \mathrm{pl}=-2.75$ to $-3 \mathrm{MPa})$ resulted in a complete break down of resistance in $P$. radiata, with a ten-fold increase of lesions [43]. The rapid onset of disease in pines when they are exposed to stress could be explained by the role of latent infections. Whereas $S$. sapinea was confined to inactive pith tissues of mature seed cones in non-stressed trees, an extensive colonisation of branch and stem tissues spreading from cones was found in trees damaged by hail [182]. Stanosz et al. [187] provided strong experimental evidence of the role of $S$. sapinea in the death of non-inoculated asymptomatic seedlings which had been subjected to water stress.

Outbreaks of $S$. sapinea have been ascribed to other potential factors associated with global change: warming temperatures (the optimum growth temperature of $S$. sapinea is close to $30{ }^{\circ} \mathrm{C}$, [42], nitrogen deposition [62], and increased trade resulting in new introductions, including strains of higher virulence (especially via asymptomatic infected seeds) [181,218].

\subsection{Biscogniauxia mediterranea-Quercus}

Biscogniauxia mediterranea (De Not.) Kuntze. (syn. Hypoxylon mediterraneum (De Not.) Mill.) is an opportunistic parasite responsible for necrosis on stems and branches of Quercus species in the Mediterranean area, known as "charcoal disease". It is reported from Africa, Central America, Europe, USA and Russia [91, 172] on a wide range of hosts. The name of the disease originates from the black stromata forming on the dead branches and stems. Its incidence is particularly alarming on $Q$. suber [196]. However, it causes serious damage also on $Q$. cerris, $Q$. frainetto, $Q$. pubescens and
Q. ilex $[38,200]$. In environmentally predisposed oak sites incidence of charcoal disease on $Q$. cerris and $Q$. frainetto was over 50\% [204].

Symptoms of B. mediterranea attack on Quercus spp. are not easy to distinguish from those typical of water stress; however they include a gradual generally basipetal crown wilt that can involve the whole crown within 1 or 2 seasons, depending on intensity of water stress. Necrosis of bark and black necrotic lines in the wood are present along stems and branches. A severe wood discoloration generally delimited by a black line is evident in transverse sections of stems or branches [200]. These symptoms are accompanied by the presence of signs of $B$. mediterranea attack, including black stromata erupting from bark tissues and developing longitudinally up to several meters. Stromata contain perithecia of the fungus. Ascospores are actively ejected from perithecia in wet periods and represent the main source of inoculum [203]. Ascospores are dispersed by wind and rain splash; however evidence is reported for the involvement of the genus Agrilus as vector of $B$. mediterranea [202]. Buds and microwounds are believed to be the primary sites of infection of this fungus [203]. B. mediterranea commonly lives as endophyte in tissues of healthy vigorous oaks, including leaves, twigs and bark [4,48, 131, 199]. It can be stated that this fungus is a typical component of the endophytic micro flora inhabiting Quercus spp. in the Mediterranean forests. Recent investigations carried out in Italy reported $B$. mediterranea being present, in both the endophytic and pathogenic phases, in Southern and Central Italy while it was not detected in oak forests in northern Italy above $45^{\circ}$ latitude [5].

Abundance of $B$. mediterranea in tissues and its ability to shift from the endophytic to the pathogenic phase is mediated by water stress conditions of the host. As demonstrated by Lucero [114], there is a significant correlation between the abundance of $B$. mediterranea in asymptomatic tissues and the decrease of leaf water potential of the host plant. This finding is consistent with the higher frequency of isolation in autumn compared with spring, following the summer drought typical of Mediterranean regions [48, 115]. During its endophytic phase, $B$. mediterranea is nearly absent from woody tissues [4,114]. However, invasion and discoloration of wood is typical of the pathogenic phase of the fungus [200]. When the tree or part of it is subjected to severe water stress, $B$. mediterranea develops rapidly within the xylem, preferentially spreading through the large air-embolized vessels and apparently killing the adjacent parenchyma [201]. The entire host may soon die, probably owing to synergistic colonization of tissues from several infection points where the fungus was latently present. Combined physiological and pathological studies showed that a leaf water potential around $-3.5 \mathrm{Mpa}$ corresponds in $Q$. cerris to up to $66 \%$ loss in conductivity and massive invasion of woody tissues by the fungus results [201]. Furthermore, at a leaf water potential between -3.0 and $-3.5 \mathrm{Mpa}$ the flux density dramatically drops suggesting diffuse cavitation of vessels. Oak species differ in susceptibility to $B$. mediterranea depending on their performance under drought conditions [204]. As an example the higher susceptibility of $Q$. cerris to the fungus, compared with $Q$. pubescens, 
is associated with more negative PWP values than the latter species, at the same water supply level [204]. Observations carried out in mixed oak forests in Central and Southern Italy, showed that heavy attacks of $B$. mediterranea following one or more seasons of severe drought, noticeably change the species composition of the biocenosis favouring the survival of the most xerophytic species, $Q$. pubescens, and the reduction in number of individuals of $Q$. cerris and $Q$. frainetto [204]. In coppices heavily attacked by $B$. mediterranea, $56.8 \%$ of $Q$. cerris trees died compared with only $1.9 \%$ of $Q$. pubescens, after severe drought conditions [204]. In old abandoned coppices in which species composition has been directed by anthropic pressure, $B$. mediterranea acts as a beneficial factor in the biocenosis, by reducing the biomass and modulating the species composition.

\subsection{Possible role of root pathogens in declines associated with drought}

The role of root pathogens in drought induced declines is usually not easy to determine. The case of Armillaria species is typical. Armillaria spp. have been commonly reported in the literature to be associated with declines following drought (for a review, see [211]) and species such as A. gallica and A. cepistipes are known to be secondary pathogens, i.e. pathogens unable to invade trees unless they are stressed by another factor [78]. Unfortunately, the Armillaria species involved in the reported decline cases are often not known because many of the reports are older than 1980. Most of these reports relate to oaks and firs. Also, A. ostoyae has a higher prevalence on coarse texture soils [50,122, 134, 177, 193,216,217] and these soils have a low water reserve. This could be an indication that this species is more aggressive on conifers subjected to water shortage. However, controlled condition experiments testing the effect of water stress on tree susceptibility to Armillaria spp. do not show a clear trend.

The two studies conducted on pines suggest that the susceptibility of these species to A. ostoyae is not increased by a water shortage $[115,207]$. Both were conducted on potted seedlings and the severity of A. ostoyae infections was increased neither for $P$. sylvestris nor for $P$. pinaster seedlings subjected to water shortage compared to control seedlings. The lack of drought impact in these experiments might be related to the scarcity of reports of pine decline involving Armillaria species following drought [211]. By contrast, an inoculation study with 3-year-old Abies grandis showed a clear increase of seedling susceptibility to A. ostoyae following a water stress [153]. Comparatively, very little work has been done on broadleaf trees, and in particular on oaks that are however most represented in reports of decline associated with drought and Armillaria [211]. Anselmi and Puccinelli [3] studied the impact of a water shortage on the susceptibility of several oak species to A. gallica and A. mellea. Oak seedlings inoculated by $A$. mellea and watered with only a third of the amount of water given to the controls experienced increased mortality compared to non-inoculated and water stressed oak seedlings. Experiments conducted on mature trees are scarce.
Walström and Barklund [206] induced an artificial drought on 26-year-old Picea abies inoculated with A. ostoyae and A. borealis by preventing rain water from reaching the soil. After 5 months, trees experiencing the water shortage did not differ in susceptibility to the tested Armillaria species from the control trees.

The interaction between trees, pathogens and stressful environmental conditions has been mainly examined through the enhancement of plant susceptibility to pathogens by stress, with pathogens playing the role of contributory factors in the decline process, according to Manion's terminology. However, in many cases, this proved to be difficult to demonstrate. Another possible mechanism is a lower ability of infected trees to withstand the stress, infection playing the role of a predisposing factor of decline. For example, Collybia fusipes has a higher impact on Quercus robur in stands with low soil waterlogging and a coarse texture [36]. However, efforts to demonstrate that oak trees growing in sandy soils or subjected to water shortage were more susceptible to $C$. fusipes were not successful $[35,37]$. Furthermore, it was demonstrated that, at a given level of root destruction by $C$. fusipes, the likelihood of decline of a tree was greater in a sandy loam compared to a clay loam $[36,126]$. This could be explained by a decreased ability of root-damaged trees to cope with situations of poor water availability. This mechanism has also been suggested to be important in the case of Phytophthora infected trees. Both field and experimental evidence support a higher vulnerability of $P$. cinnamomi infected trees to water deficits $[52,128,129]$. The death of roots, particularly roots extracting water deep in the soil, may be especially critical in sites with low water availability [53]. This may explain the pattern of $P$. cinnamomi induced Eucalyptus decline observed in eastern Australia, where decline episodes occur in years where a hot and rainy period in late spring-early summer, promoting $P$. cinnamomi infection, is followed by a dry period in summer [197]. Several new Phytophtora ssp. have recently been described and suggested to be involved in European oak declines $[82,90,92-96]$. Although these species act as primary pathogens, their pathogenicity generally seems to be too low to induce mortality alone, yet Phytophthora spp. may act as additional stressors to oak trees [58].

\section{CONCLUSIONS}

Drought-disease interaction effects are especially important in perennial plants, such as forest trees. Forest ecosystems are less managed than agrosystems and therefore more likely subjected to effects of naturally occurring stress like drought. Moreover, long term effects of drought, spanning several years, have often been demonstrated. The nature of diseases favoured by drought may be an additional factor explaining the importance of drought-infection interactions in trees. As clearly indicated by the analysis of literature and other reports, drought-induced diseases are often caused by facultative parasites having saprophytic or endophytic abilities, developing in secondary tissues (bark/wood). These fungi live in dead parts or as latent endophytes of living trees and 
water stress is often only a revealer of their presence, by triggering host susceptibility and/or releasing pathogen quiescence. The ubiquitous nature of these parasites in natural forests, and their role as "ecosystem roguers and scavengers", by killing weakened trees and decaying dead trees, has been highlighted by Wargo [210]. However, this view, together with the naming of pathogens as non-aggressive /facultative /secondary /opportunistic may be somewhat misleading about the potential damage associated with these parasites, especially in managed forests. Productive species artificially favoured in managed forests have proved to be especially affected by drought-pathogen effects where they are not well adapted, as illustrated by the oak declines in France and Italy in the 1980s, that affected $Q$. robur and $Q$. cerris, respectively. Moreover, the experience of stress, especially water stress, by trees is a common condition during their lifespan and pathogens predisposed by drought can induce very severe damage, as shown for Sphaeropsis sapinea. Infection by primary foliar or root pathogens may reciprocally act as a predisposing factor to water stress. Very limited experimental research has been conducted at the stand/community level to study the effects of combined biotic and abiotic stress, in particular their role in exacerbating competitive interactions between trees. Clearly, a better knowledge of the relationships between diversity (both specific and genetic, including age structure and other factors of heterogeneity) and the capacity for plastic and adaptive responses at the population/community level of forest ecosystems is needed. Although experiments in grasslands support the "insurance hypothesis" that increased species diversity is associated with sustained functioning, especially improved productivity and lower pathogen load [113, 137, 138, 194], links between community properties and resistance or resilience to extreme climatic events are still poorly understood, let alone considering interactions with pathogens. Contrasted results in manipulated grasslands have been obtained on the association between plant diversity and resistance to drought, with some studies reporting lower ecosystem resistance to severe climatic stress with increased plant diversity $[156,159]$.

More specific knowledge gaps in the field of pathology relate to the pathogens commonly involved in drought-induced diseases. Increasing evidence suggests the diversity and functional importance of fungal endophytes in trees [39, 180, 187]. As shown for Biscognauxia mediterranea and Sphaeropsis sapinea, host stress may trigger shifts from latent to pathogenic stages. The occurrence of variants of high virulence selected by stress among the overall low virulent population, according to Beck's model, cannot be ruled out and should be examined. The genetic studies will also allow a clarification in the taxonomy of several groups. The taxonomic revision of Botryosphaeria (anamorphs Diplodia, Fusicoccum, Lasiodiplodia, Botryodiplodia, Sphaeropsis) has made considerable progress in recent years with the use of molecular tools $[59,150,179,215,223]$. The resolution of species complexes may help solve questions on epidemiology of these species, including host range and interaction with drought. The recent description of the new species Botryosphaeria corticola [2], differentiated from $B$. stevensii (Diplodia mutila) frequently associated with dieback and cankers of oaks in the Mediter- ranean region $[164,165]$ and sometimes in other areas, provides an illustrative example. Following the species level, the population genetics of these fungi may provide insights into their dispersal and variation in latent/pathogenic capacities.

This review was focused on drought in its interactions with pathogens. Severe drought and heat are often associated, as occurred in the summer 2003 in Europe, and in previous episodes. The literature on heat stress is relatively scarce, especially in trees. The eruption of sooty bark disease of sycamore in Great Britain was at first assumed to be linked to high temperatures in summer, as in 1947 and 1949. However, the comparison of disease levels in years similar in terms of temperature but differing for the moisture deficit suggested a more important role of drought, as also supported by experimental evidence [74]. The evolution of climate in temperate regions may specifically favour thermophilic fungi able to persist in trees until the water regime is disrupted, as exemplified by $C$. corticale, $B$. mediterranea, $S$. sapinea. Pathogens of Mediterranean or tropical origin extending their geographic range in response to climate change represent a serious threat.

Straightforward implications for forest management of drought-pathogen interactions are to prevent as much as possible both water stress in trees during drought episodes [29] and pathogen damage. The foremost prevention measure for pathogens is to avoid dispersal by means of infected material used for plantations. Infected seed and nursery plants are important pathways of pathogen dispersal. The problem is even more crucial with latent pathogens often involved in droughtinduced diseases, since they can persist in tissues asymptomatically. The improvement of diagnostic tools and methodology to assess their prevalence is clearly needed. Although scientific support has still to be provided in the diversity-stability debate, biological diversity in all its components is a key factor to be considered in forest management, enabling populations and communities to adapt to environmental change.

\section{REFERENCES}

[1] Agrios G.N., Plant pathology, 5th ed., Academic Press, 2005.

[2] Alves A., Correia A., Luque J., Phillips A., Botryosphaeria corticola sp. nov. on Quercus species, with notes on Botryosphaeria stevensii and its anamorph, Diplodia mиtila, Mycologia 96 (2004) 598-613.

[3] Anselmi N., Puccinelli P., Studies on Armillaria attacks on declining oak trees, in: Luisi N., Lerario P., Vannini A. (Eds.), Recent advances in Studies on oak decline, Universita degli studi, Bari, Italia, 1992, pp. 23-29.

[4] Anselmi N., Mazzaglia A., Vannini A., The role of endophytes in oak decline, in: Ragazzi A., DellaValle I. (Eds.), Decline of oak species in Italy problems and perspectives, Accad. Sci. For., Firenze, 2000, pp. 129-144.

[5] Anselmi N., Celerino G.P., Franceschini A., Granata G., Luisi N., Marras F., Mazzaglia A., Mutto Accordi S., Ragazzi A., Geographic distribution of fungal endophytes of Quercus spp. in Italy, in: Ragazzi A., Moricca S., Dellavalle I. (Eds.), Endophytism in forest trees, Accad. It. Sci. For., Firenze, 2004, pp. 75-89.

[6] Appel D.N., Stipes R.J., Canker expansion on water-stressed pin oaks colonized by Endothia gyrosa, Plant Dis. 68 (1984) 851-853.

[7] Appel K., Hirt H., Reactive oxygen species: metabolism, oxidative stress, and signal transduction, Annu. Rev. Plant. Biol. 55 (2004) 373-399. 
[8] Arevallo-Ferro C., Hentzer M., Reil G., Görg A., Kjelleberg S., Givskov M., Riedel K., Eberl L., Identification of quorum sensing regulated proteins in the opportunistic pathogen Pseudomonas aeruginosa by proteomics, Environ. Microbiol. 12 (2003) 1350 1369.

[9] Asiegbu F.O., Nahalkova J., Li G.S., Pathogen-inducible cDNAs from the interaction of the root rot fungus Heterobasidion annosum with Scots pine (Pinus sylvestris L.), Plant Sci. 168 (2005) 365-372.

[10] Ayres P.G., Growth responses induced by pathogens and other stresses, in: Mooney H.A., Winner W.E., Pell E.J., Chu E. (Eds.), Response of plants to multiple stresses, Academic Press, 1991, pp. 227-248.

[11] Bachi P.R., Peterson J.L., Enhancement of Sphaeropsis sapinea stem invasion of pines by water deficits, Plant Dis. 69 (1985) 798799.

[12] Bagga D.K., Smalley E.B., The development of Hypoxylon canker of Populus tremuloides role of interacting environmental factors, Phytopathology 64 (1974) 658-662.

[13] Beck M.A., Handy J., Levander O.A., Host nutritional status: the neglected virulence factor, Trends Microbiol. 12 (2004) 417-423.

[14] Becker M., Lévy G., Le dépérissement du chêne en forêt de Tronçais. Les causes écologiques, Ann. Sci. For. 39 (1982) 439444.

[15] Belanger R.R., Manion P.D., Griffin D.H., Amino acid content of water-stressed plantlets of Populus tremuloides clones in relation to clonal susceptibility to Hypoxylon mammatum in vitro, Can. J. Bot. 68 (1990) 26-29.

[16] Bendz-Hellgren M., Stenlid J., Effects of clear-cutting, thinning, and wood moisture content on the susceptibility of Norway spruce stumps to Heterobasidion annosum, Can. J. For. Res. 28 (1998) 759-765.

[17] Bevercombe G.P., Rayner A.D.M., Diamond-bark diseases of sycamore in Britain, New Phytol. 86 (1980) 379-382.

[18] Bier J.E., The relation of bark moisture to the development of canker diseases caused by native, facultative parasites. I Cryptodiaporthe canker on willow, Can. J. Bot. 37 (1959) 229 238.

[19] Bier J.E., The relation of some bark factors to canker susceptibility, Phytopathology 54 (1964) 250-253.

[20] Blaker N.S., MacDonald J.D., Predisposing effects of soil moisture extremes on the susceptibility of rhododendron to Phytophthora root and crown rot, Phytopathology 71 (1981) 831-834.

[21] Blodgett J.T., Stanosz G.R., Sphaeropsis sapinea morphotypes differ in aggressiveness, but both infect nonwounded red or jack pines, Plant Dis. 81 (1997) 143-147.

[22] Blodgett J.T., Stanosz G.R., Differences in aggressiveness of Sphaeropsis sapinea RAPD marker group isolates on several conifers, Plant Dis. 83 (1999) 853-856.

[23] Blodgett J.T., Kruger E.L., Stanosz G.R., Effects of moderate water stress on disease development by Sphaeropsis sapinea on red pine, Phytopathology 87 (1997) 422-428.

[24] Blodgett J.T., Kruger E.L., Stanosz G.R., Sphaeropsis sapinea and water stress in a red pine plantation in central Wisconsin, Phytopathology 87 (1997) 429-434.

[25] Boddy L., Effect of temperature and water potential on growth rate of wood-rotting basidiomycetes, 80 (1983) 141-149.

[26] Bowler C., Fluhr R., The role of calcium and activated oxygens as signals for controlling cross-tolerance, Trends Plant Sci. 5 (2000) 241-246.

[27] Boyer J.S., Biochemical and biophysical aspects of water deficits and the predisposition to disease, Ann. Rev. Phytopathol. 33 (1995) 251-274
[28] Brasier C.M., Phytophthora cinnamomi and oak decline in southern Europe. Environmental constraints including climate change, Ann. Sci. For. 53 (1996) 347-358.

[29] Breda N., Huc R., Granier A., Dreyer E., Forest trees and stands under drought: a review of ecophysiological responses, adaptation processes and long-term consequences, Ann. Sci. For. 63 (2006) 623-642.

[30] Britton K.O., Anthracnose infection of dogwood seedlings exposed to natural inoculum in western North Carolina, Plant Dis. 77 (1993) 34-37.

[31] Bruck R.I., Manion P.D., Interacting environmental factors associated with the incidence of Hypoxylon canker on trembling aspen, Can. J. For. Res. 10 (1980) 17-24.

[32] Bunny F.J., Crombie D.S., Williams M.R., Growth of lesions of Phytophthora cinnamomi in stems and roots of jarrah (Eucalyptus marginata) in relation to rainfall and stand density in mediterranean forest of Western Australia, Can. J. For. Res. 25 (1995) 961-969.

[33] Burgess T., Wingfield B.D., Wingfield M.J., Comparison of genotypic diversity in native and introduced populations of Sphaeropsis sapinea isolated from Pinus radiata, Mycol. Res. 105 (2001) 1331-1339.

[34] Burgess T.I., Wingdield M.J., Wingfield B.D., Global distribution of Diplodia pinea genotypes revealed using simple sequence repeat (SSR) markers, Austr. Plant Pathol. 33 (2004) 513-519.

[35] Camy C., Influence des facteurs édaphiques et sylvicoles sur le développement du pourridié à collybie (Collybia fusipes) dans la chênaie pédonculée, Thèse de l'université Nancy I, 2002.

[36] Camy C., De Villebonne D., Delatour C., Marçais B., Soil factors associated with decline of oaks and infection by Collybia fusipes, For. Pathol. 33 (2003) 253-266.

[37] Camy C., Delatour C., Caël O., Marçais B., Inoculation of mature pedunculate oaks (Quercus robur) with the root rot fungus Collybia fusipes: Relationships with tree vigour and soil factors, Eur. J. Plant Pathol. 109 (2003) 545-553.

[38] Capretti P., Mugnai L., Dieback of Quercus cerris caused by Hypoxylon mediterraneum (De Not.) Mill., Informatore Fitopatologico 37 (1987) 39-41.

[39] Chapela I.H., Boddy L., Fungal colonization of attached beech branches. II. Spatial and temporal organization of communities arising from latent invaders in bark and functional sapwood, under different moisture regimes, New Phytol. 110 (1988) 47-57.

[40] Chini A., Grant J.J., Seki M., Shinozaki K., Loake G.J., Drought tolerance established by enhanced expression of the CC-NBSLRR gene, ADR1, requires salicylic acid, EDS1 and ABI1, Plant J. 38 (2004) 810-822.

[41] Chou C.K.S., Penetration of young stems of Pinus radiata by Diplodia pinea, Physiol. Plant Pathol. 13 (1978) 189-192.

[42] Chou C.K.S., Diplodia pinea infection of Pinus radiata seedlings: effects of temperature and wetness duration, N. Z. J. For. Sci. 12 (1982) 425-437.

[43] Chou C.K.S., Crown wilt of Pinus radiata associated with Diplodia pinea infection of woody stems, Eur. J. For. Pathol. 17 (1987) 398-411.

[44] Chou C.K.S., MacKenzie M., Effect of pruning intensity and season on Diplodia pinea infection of Pinus radiata stem through pruning wounds, Eur. J. For. Pathol. 18 (1988) 437-444.

[45] Clinton B.D., Boring L.R., Swank W.T., Canopy gap characteristics and drought influences in oak forests of the Coweeta Basin, Ecology 74 (1993) 1551-1558.

[46] Clinton B.D., Yeakley J.A., Apsley D.K., Tree growth and mortality in a southern Appalachian deciduous forest following extended wet and dry periods, Castanea 68 (2003) 189-200.

[47] Colhoun J., Effects of environmental factors on plant disease, Ann. Rev. Phytopathol. 11 (1973) 343-364. 
[48] Collado J., Platas G., Pelaez F., Identification of an endophytic Nudulisporium sp. from Quercus ilex in central Spain as the anamorph of Biscogniauxia mediterranea by rDNA sequence analysis and effect of different ecological factors on distribution of the fungus, Mycologia 93 (2001) 875-886.

[49] Cook R.J., Papendick R.I., Influence of water potential of soils and plants on root disease, Ann. Rev. Phytopathol. 10 (1972) 349-374.

[50] Côté E., Dessureault M., Effects of site factors on the occurrence of Armillaria root rot disease in black spruce (Picea mariana [Mill.] B.S.P.) seed orchards, in: Johansson M., Stenlid J. (Eds.), Proc. eighth int. conf. on root and butt rots, Swedish University of Agricultural Sciences, Uppsala, 1994, pp. 592-596.

[51] Crist C.R., Schoeneweiss D.F., The influence of controlled stresses on susceptibility of European white birch stems to attack by Botryosphaeria dothidea, Phytopathology 65 (1975) 369-373.

[52] Crombie D.S., Tippett J.T., A comparison of water relations, visual symptoms, and changes in stem girth for evaluating impact of Phytophthora cinnamomi dieback on Eucalyptus marginata, Can. J. For. Res. 20 (1990) 233-240.

[53] Crombie D.S., Tippett J.T., Gorddard D.J., Water relations of rootpruned jarrah (Eucalyptus marginata Donn ex Smith) saplings, Aust. J. Bot. 35 (1987) 653-663.

[54] Dangl J.L., Jones J.D.G., Plant pathogens and integrated defence responses to infection, Nature 411 (2001) 826-833.

[55] Daughtrey M.L., Hibben C.R., Dogwood anthracnose: a new disease threatens two native Cornus species, Ann. Rev. Phytopathol. 32 (1994) 61-73.

[56] Davison E.M., Tay F.C.S., Peroni D., Sphaeropsis sapinea on pines in Western Australia, Austr. Plant Pathol. 20 (1991) 31.

[57] Delatour C., Oak dieback in Europe, Rev. For. Fr. 35 (1983) 265282.

[58] Delatour C., Anselmi N., Barzanti P., Bianco M.C., Blaschke H., Brasier C.M., Capretti P., Desprez-Loustau M.L., Dreyer E., Hansen E.M., Heyne C., Jung T., Luisi N., Marçais B., Matyssek R., Maurel M., Oßwald W., Paoletti E., Ragazzi A., Robin C., Vannini A., Vettraino A.M., Phytophthora in the European oak forest, Second Int. Meeting on Phytophthora in Forests and Natural Ecosystems, Albany, Western Australia 30 September-5 October 2001.

[59] Denman S., Crous P.W., Groenewald J.Z., Slippers B., Wingfield B.D., Wingfield M.J., Circumscription of Botryosphaeria species associated with Proteaceae based on morphology and DNA sequence data, Mycologia 95 (2003) 294-307.

[60] Desprez-Loustau M.L., Dessureault M., Influence of controlled stresses on the sensitivity of yellow birch to canker caused by Godronia cassandrae f. sp. betulicola, Can. J. For. Res. 18 (1988) 121-127.

[61] Dickenson S., Wheeler B.E.J., Effects of temperature, and water stress in sycamore, on growth of Cryptostroma corticale, Trans. Br. Mycol. Soc. 76 (1981) 181-185.

[62] Dijk H.F.G. van, Gaag M. van der, Perik P.J.M., Roelfs J.G.M., Nutrient availability in Corsican pine stands in the Netherlands and the occurrence of Sphaeropsis sapinea: a field study, Can. J. Bot. 70 (1992) 870-875.

[63] Duniway J.M., Water relations of water molds, Ann. Rev. Phytopathol. 17 (1979) 431-460.

[64] Duniway J.M., Role of physical factors in the development of Phytophthora diseases, in: Erwin D.C., Bartnicki-Garcia S., Tsao P.H. (Eds.), Phytophthora: its Biology, Taxonomy, Ecology and Pathology, St Paul, Minnesota, APS Press, 1983, pp. 175-187.

[65] Duniway J.M., Gordon T.R., Water relations and pathogen activity in soil, in: Ayres P.G., Boddy L. (Eds.), Water, fungi and plants, Cambridge University Press, 1986, pp. 119-137.

[66] Eamus D., Jennings D.H., Water, Turgor and osmotic potentials of fungi, in: Ayres P.G., Boddy L. (Eds.), Water, fungi and plants, Cambridge University Press, 1986, pp. 27-48.
[67] Erbaugh D.K., Windham M.T., Stodola A.J.W., Auge R.M., Light intensity and drought stress as predisposition factors for dogwood anthracnose, J. Environ. Hortic. 13 (1995) 186-189.

[68] Ersoz E.S., Gonzalez-Martinez S., Gill G., Brown G., Morse A., Davis J., White T., Neale D.B., SNP discovery in candidate genes for disease resistance (Pitch canker and fusiform rust) and drought tolerance in loblolly pine, Plant and animal genomes, XII Conference, San Diego, 2004.

[69] Flowers J., Nuckles E., Hartman J., Vaillancourt L., Latent infection of Austrian and Scots pine tissues by Sphaeropsis sapinea, Plant Dis. 85 (2001) 1107-1112.

[70] Flowers J., Hartman J., Vaillancourt L., Detection of latent Sphaeropsis sapinea infections in Austrian pine tissues using nested-polymerase chain reaction, Phytopathology 93 (2003) 1471-1477.

[71] Fonseca N., Control measures for the major forest nursery diseases in Portugal, in: Perrin R., Sutherland J.R. (Eds.), Diseases and insects in forest nurseries, INRA Paris, 1994.

[72] Frey B.R., Lieffers V.J., Hogg E.H., Landhausser S.M., Predicting landscape patterns of aspen dieback: mechanisms and knowledge gaps, Can. J. For. Res. 34 (2004) 1379-1390.

[73] Gao S., Shain L., Effects of water stress on chestnut blight, Can. J. For. Res. 25 (1995) 1030-1035.

[74] Gibbs J.N., Fifty years of sooty bark disease of sycamore, Q. J. For. 91 (1997) 215-221.

[75] Gibbs J.N., Greig B.J.W., Some consequences of the 1975-1976 drought for Dutch elm disease in southern England, Forestry 50 (1977) 145-154.

[76] Gould A.B., Peterson J.L., The effect of moisture and sunlight on the severity of dogwood anthracnose in street trees, J. Arbor. 20 (1994) 75-78.

[77] Gregory S.C., Bark necrosis of Acer pseudoplatanus L. in northern Britain, Eur. J. For. Pathol. 12 (1982) 157-167.

[78] Gregory S.G., Rishbeth J., Shaw C.G. III, Pathogenicity and virulence, in: Shaw C.G., Kile G.A. (Eds.), Armillaria root disease, Agriculture handbook 691, US Depart. Agric. For. Serv. 1991, pp. 76-87.

[79] Griffin D.M., Water potential and wood-decay fungi, Ann. Rev. Phytopathol. 15 (1977) 319-329.

[80] Guillaumin J.J., Bernard C., Delatour C., Belgrand M., Contribution to the study of oak dieback: root pathology in the forest of Tronçais, Ann. Sci. For. 42 (1985) 1-22.

[81] Guyon J.C., Jacobi W.R., McIntyre G.A., Effects of environmental stress on the development of Cytospora canker of aspen, Plant Dis. 80 (1996) 1320-1326.

[82] Hansen E., Delatour C., Phytophthora species in oak forests of north-east France, Ann. Sci. For. 56 (1999) 539-547.

[83] Hendry S.J., Lonsdale D., Boddy L., Strip-cankering of beech (Fagus sylvatica): pathology and distribution of symptomatic trees, New Phytol. 140 (1998) 549-565.

[84] Hepting G.H., Climate and forest diseases, Ann. Rev. Phytopathol. 1 (1963) 31-50.

[85] Hogg E.H., Brandt J.P., Kochtubajda B., Growth and dieback of aspen forests in northwestern Alberta, Canada, in relation to climate and insects, Can. J. For. Res. 32 (2002) 823-832.

[86] IPCC, Climate Change 2001, The scientific basis, Contribution of Working Group I to the third assessment report of the IPCC, Houghton J.T., Ding Y., Griggs D.J., Noguer M., Van der Linder P.J., Dai X., Maskell K., Johnson C.A. (Eds.), Cambridge University Press, Cambridge, UK, 2001.

[87] Jacobi W.R., Riffle J.W., Effects of water stress on Thyronectria canker of honeylocusts, Phytopathology 79 (1989) 1333-1337.

[88] Jactel H., Petit J., Piou D., Desprez-Loustau M.L., A meta-analysis of forest pest and disease response to water stress, Conference 
"Impacts of the Drought and Heat in 2003 on Forests", 17-19 November 2004, Freiburg im Breisgau, Germany.

[89] Johnson J.W., Gleason M.L., Parker S.K., Provin E.B., Iles J.K., Flynn P.H., Duration of water stress affects development of Sphaeropsis canker on Scots pine, J. Arbor. 23 (1997) 73-76.

[90] Jonsson U., Lundberg L., Sonesson K., Jung T., First records of soilborne Phytophthora species in Swedish oak forests, For. Pathol. 33 (2003) 175-179.

[91] Ju Y.-M., Rogers J.D., San Martin F., Granmo A., The genus Biscogniauxia, Mycotaxon 66 (1998) 1-98.

[92] Jung T., Blaschke H., Neumann P., Isolation, identification and pathogenicity of Phytophthora species from declining oak stands, Eur. J. For. Pathol. 26 (1996) 253-272.

[93] Jung T., Cooke D.E.L., Blaschke H., Duncan J.M., Osswald W., Phytophthora quercina sp. nov., causing root rot of European oaks, Mycol. Res. 103 (1999) 785-798.

[94] Jung T., Blaschke H., Osswald W., Involvement of soilborne Phytophthora species in Central European oak decline and the effect of site factors on the disease, Plant Pathol. 49 (2000) 706-718.

[95] Jung T., Hansen E.M., Winton L., Osswald W., Delatour C., Three new species of Phytophthora from European oak forests, Mycol. Res. 106 (2002) 397-411.

[96] Jung T., Nechwatal J., Cooke D.E.L., Hartmann G., Blaschke M., Osswald W.F., Duncan J.M., Delatour C., Phytophthora pseudosyringae sp. nov., a new species causing root and collar rot of deciduous tree species in Europe, Mycol. Res. 107 (2003) 772-789.

[97] Kam M. de, Dam B.C.V. et al., A serious epidemic of Sphaeropsis sapinea in the Netherlands and the role of ammonium deposition as an epidemiological factor, Mets. Tied. 360 (1990) 93-97.

[98] Kam M. de, Versteegen C.M., Burg J. van den, Werf D.C. van der, Effects of fertilization with ammonium sulphate and potassium sulphate on the development of Sphaeropsis sapinea in Corsican pine, Neth. J. Plant Pathol. 97 (1991) 265-274

[99] Kay S.J., Chee A.A., Sale P.O., Taylor J.T., Hadar E., Hadar Y., Farrell R.L., Variation among New Zealand isolates of Sphaeropsis sapinea, For. Pathol. 32 (2002) 109-121.

[100] Kepley J.B., Jacobi W.R., Pathogenicity of Cytospora fungi on six hardwood species, J. Arbor. 26 (2000) 326-333.

[101] Kirisits T., Fungal associates of European bark beetles with special emphasis on the Ophiostomatoid fungi, in: Lieutier F., Day K.R., Battisti A., Grégoire J.-C., Evans H. (Eds.), Bark and Wood Boring Insects in Living Trees in Europe, a Synthesis, Kluwer Academic Publishers, Dordrecht, 2004, pp. 181-235.

[102] Klepzig K.D., Flores-Otero J., Hostetter R.W., Ayres M.P., Effects of available water on growth and competition of southern pine beetle associated fungi, Mycol. Res. 108 (2004) 183-188.

[103] Koricheva J., Larsson S., Haukioja E.B377, Insect performance on experimentally stressed woody plants: a meta-analysis, Ann. Rev. Entomol. 43 (1998) 195-216.

[104] Kruger B.M., Manion P.D., Antifungal compounds in aspen: effect of water stress, Can. J. Bot. 72 (1994) 454-460.

[105] Lacey L., Water availability and fungal reproduction: patterns of spore production, liberation and dispersal, in: Ayres P.G., Boddy L. (Eds.), Water, fungi and plants, Cambridge University Press, 1986, pp. 65-86.

[106] Leaphart C.D., Stage A.R., Climate: A factor in the origin of the pole blight disease of Pinus monticola Doug, Ecology 52 (1971) 229-239.

[107] Lehtijarvi A., Barklund P., Effects of irrigation, fertilization and drought on the occurrence of Lophodermium piceae in Picea abies needles, Scand. J. For. Res. 14 (1999) 121-126.

[108] Leshem Y.Y., Kuiper P.J.C., Is there a GAS (general adaptation syndrome) response to various types of environmental stress? Biol. Plant. 38 (1996) 1-18.
[109] Levy G., Delatour C., Becker M., Le dépérissement du chêne des années 1980 dans le centre de la France, point de départ d'une meilleure compréhension de l'équilibre et de la productivité de la chênaie, Rev. For. Fr. 5 (1994) 495-503.

[110] Lewis R. Jr., Arsdel E.P. van, Vulnerability of water-stressed sycamores to strains of Botryodiplodia theobromae, Plant Dis. 62 (1978) 62-63.

[111] Lindberg M., Johansson M., Resistance of Picea abies seedlings to infection by Heterobasidion annosum in relation to drought stress, Eur. J. For. Pathol. 22 (1992) 115-124.

[112] Liu R.J., Ekramoddoullah A.K.M., Zamani A., A class IV chitinas gene is up-regulated by fungal infection and abiotic stress and associated with slow-canker-growth resistance to Cronartium ribicola in western white pine (Pinus monticola), Phytopathology 95 (2005) 284-291.

[113] Loreau M., Naeem S., Inchausti P., Bengtsson J., Grime J.P., Hector A., Hooper D.U., Huston M.A., Raffaelli D., Schmid B. Tilman D., Wardle D.A., Biodiversity and ecosystem functioning: current knowledge and future challenges, Science 294 (2001) 804 808 .

[114] Lucero G.S., Ruolo dello stress idrico nella dinamica degli inoculi e negli attacchi di Biscogniauxia mediterranea, Armillaria spp. e Phytophthora spp. nel deperimento delle querce, University of Tuscia, Ph.D. thesis, 2000.

[115] Lung-Escarmant B., Desprez-Loustau M.L., Loustau D., Giraud A., Capron G., Effects of nutrient and water stress on Armillaria disease incidence in maritime pine, Information Report Laurentian Forestry Centre, Quebec Region, Can. For. Serv. LAUX-126 (2003) 117-121.

[116] Luque J., Parlade J., Pera J., Pathogenicity of fungi isolated from Quercus suber in Catalonia (NE Spain), For. Pathol. 30 (2000) 247-263.

[117] Ma Z.H., Morgan D.P., Michailides T.J., Effects of water stress on Botryosphaeria blight of pistachio caused by Botryosphaeria dothidea, Plant Dis. 85 (2001) 745-749.

[118] Madar Z., Solel Z., Kimchi M., Effect of water stress in cypress on the development of cankers caused by Diplodia pinea f. sp. cupressi and Seiridium cardinale, Plant Dis. 73 (1989) 484-486.

[119] Madar Z., Solel Z., Riov J., Sztejnberg A., Phytoalexin production by cypress in response to infection by Diplodia pinea f. sp. $\mathrm{cu}$ pressi and its relation to water stress, Physiol. Mol. Plant Pathol. 47 (1995) 29-38.

[120] Madar Z., Solel Z., Kimchi M., Enhancement of Sphaeropsis canker of Aleppo pine by the Israeli pine bast scale, Phytoparasitica 33 (2005) 28-32.

[121] Malajczuk N., Theodorou C., Influence of water potential on growth and cultural characteristics of Phytophthora cinnamomi, Trans. Br. Mycol. Soc. 72 (1979) 15-18.

[122] Mallett K.I., Maynard D.G., Armillaria root disease, stand characteristics, and soil properties in young lodgepole pine, For. Ecol. Manage. 105 (1998) 37-44.

[123] Manion P.D., Tree disease concepts, Prentice-Hall, Englewood Cliffs, New Jersey, USA, 1991.

[124] Manion P.D., Lachance D.L., Forest decline concepts: an overview, in: Manion P.D., Lachance D.L. (Eds.), Forest decline concepts, APS Press, St Paul, Minnesota, USA, 1992, pp. 181190.

[125] Marcais B., Dupuis F., Desprez-Loustau M.L., Influence of water stress on susceptibility of red oak (Quercus rubra) to Phytophthora cinnamomi, Eur. J. For. Pathol. 23 (1993) 295-305.

[126] Marçais B., Caël O., Delatour C., Relationship between aboveground signs and symptoms and root infection by Collybia fusipes in oaks, For. Pathol. 30 (2000) 7-17.

[127] Marks G.C., Smith I.W., The Cinnamon Fungus in Victorian forests, Victorian Government Publication, Dept. Conserv. Environ. Lands For. Bull. 31 (1991) 1-33. 
[128] Maurel M., Robin C., Capron G., Desprez-Loustau M.L., Effects of root damage associated with Phytophthora cinnamomi on water relations, biomass accumulation, mineral nutrition and vulnerability to water deficit of five oak and chestnut species, For. Pathol. 31 (2001) 353-369

[129] Maurel M., Robin C., Capdevielle X., Loustau D., DesprezLoustau M.L., Effects of variable root damage caused by Phytophthora cinnamomi on water relations of chestnut saplings, Ann. Sci. For. 58 (2001) 639-651.

[130] Maxwell D.L., Kruger E.L., Stanosz G.R., Effects of water stress on colonization of poplar stems and excised leaf disks by Septoria musiva, Phytopathology 87 (1997) 381-388.

[131] Mazzaglia A., Anselmi N., Gasbarri A., Vannini A., Development of polymerase chain reaction assay for the specific detection of Biscogniauxia mediterranea living as an endophyte in oak tissues, Mycol. Res. 105 (2001) 952-956.

[132] McElrone A.J., Sherald J.L., Forseth I.N., Interactive effects of water stress and a xylem-limited bacterial infection on the water relations of a host vine, J. Exp. Bot. 54 (2003) 419-430.

[133] McIntyre G.A., Jacobi W.R., Ramaley A.W., Factors affecting Cytospora canker occurrence on aspen, J. Arbor. 22 (1996) 229223.

[134] McLaughlin J.A., Distribution, hosts, and site relationships of Armillaria spp. in central and southern Ontario, Can. J. For. Res. 31 (2001) 1481-1490.

[135] McPartland J.M., Schoeneweiss D.F., Hyphal morphology of Botryosphaeria dothidea in vessels of unstressed and droughtstressed stems of Betula alba, Phytopathology 74 (1984) 358-362.

[136] Mikolajczyk M., Awotunde O.S., Muszynska G., Klessig D.F., Dobrowolska G., Osmotic stress induces rapid activation of a salicylic acid-induced protein kinase and a homolog of protein kinase ASK1 in tobacco cells, Plant Cell 12 (2000) 165-178.

[137] Mitchell C.E., Tilman D., Groth J.V., Effects of grassland plant species diversity, abundance, and composition on foliar fungal disease, Ecology 83 (2002) 1713-1726.

[138] Mitchell C.E., Reich P.B., Tilman D., Groth J.V., Effects of elevated $\mathrm{CO}_{2}$, nitrogen deposition, and decreased species diversity on foliar fungal plant disease, Glob. Change Biol. 9 (2003) 438-451.

[139] Morelet M., Chandelier P., A case of variability in Sphaeropsis sapinea, Eur. J. For. Pathol. 23 (1993) 317-320.

[140] Moricca S., Phomopsis alnea, the cause of dieback of black alder in Italy, Plant Pathol. 51 (2002) 755-764.

[141] Morse A.M., Nelson C.D., Covert S.F., Holliday A.G., Smith K.E., Davis J.M., Pine genes regulated by the necrotrophic pathogen Fusarium circinatum, Theor. Appl. Gen. 109 (2004) 922-932.

[142] Mullen J.M., Gilliam C.H., Hagan A.K., Morgan-Jones G., Canker of dogwood caused by Lasiodiplodia theobromae, a disease influenced by drought stress or cultivar selection, Plant Dis. 75 (1991) 886-889.

[143] Munne-Bosch S., Penuelas J., Drought-induced oxidative stress in strawberry tree (Arbutus unedo L.) growing in Mediterranean field conditions, Plant Sci. 166 (2004) 1105-1110.

[144] Murray J.S., Death of bark in Acer pseudoplatanus associated with drought, Eur. J. For. Pathol. 8 (1978) 65-75.

[145] Nageleisen L.M., Le dépérissement actuel de feuillus divers : hêtre, merisier, alisier torminal, érable sycomore, peuplier, châtaignier, charme, aulne glutineux, Rev. For. Fr. 5 (1994) 554-562.

[146] Nageleisen L.M., Le dépérissement actuel des chênes, Rev. For. Fr. 5 (1994) 504-511.

[147] Nagy N.E., Fossdal C.G., Dalen L.S., Lonneborg A., Heldal I., Johnsen O., Effects of Rhizoctonia infection and drought on peroxidase and chitinase activity in Norway spruce (Picea abies), Physiol. Plant. 120 (2004) 465-473.
[148] Newhook F.J., Podger F.D., The role of Phytophthora cinnamomi in Australian and New Zealand forests, Ann. Rev. Phytopathol. 10 (1972) 299-326.

[149] Nicholls T.H., Ostry M.E., Sphaeropsis sapinea cankers on stressed red and jack pines in Minnesota and Wisconsin, Plant Dis. 74 (1990) 54-56.

[150] Niekerk J.M. van, Crous P.W., Groenewald J.Z., Fourie P.H., Halleen F., DNA phylogeny, morphology and pathogenicity of Botryosphaeria species on grapevines, Mycologia 96 (2004) 781798.

[151] Palmer M.A., Isolate types of Sphaeropsis sapinea associated with main stem cankers and top-kill of Pinus resinosa in Minnesota and Wisconsin, Plant Dis. 75 (1991) 507-510.

[152] Paoletti E., Danti R., Strati S., Pre- and post-inoculation water stress affects Sphaeropsis sapinea canker length in Pinus halepensis seedlings, For. Pathol. 31 (2001) 209-218.

[153] Parks C.G., Filip G.M., Hansen E.M., The influence of water stress and insect defoliation on the development of disease in Abies grandis seedlings inoculated with Armillaria ostoyae, in: Johansson M., Stenlid J. (Eds.), Proc. 8th Int. Conf. on root and butt rots, Swedish, University of Agricultural Sciences, Uppsala, 1994, pp. 52-64.

[154] Paul N.D., Ayres P.G., Effects of rust and post-infection drought on photosynthesis, growth and water relations in groundsel, Plant Pathol. 33 (1984) 561-569.

[155] Paul N.D., Ayres P.G., Water stress modifies intraspecific interference between rust (Puccinia lagenophorae Cooke) infected and healthy groundsel (Senecio vulgaris L.), New Phytol. 106 (1987) 555-566.

[156] Peer L. van, Nijs I., Reheul D., Cauwer B. de, Species richness and susceptibility to heat and drought extremes in synthesized grassland ecosystems: compositional vs. physiological effects, Funct. Ecol. 18 (2004) 769-778.

[157] Pernas M., Sanchez-Monge R., Salcedo G., Biotic and abiotic stress can induce cystatin in chestnut, FEBS lett. 467 (2000) 206210.

[158] Peterson G.W., Infection, epidemiology, and control of diplodia blight of Austrian, ponderosa, and Scots pines, Phytopathology 67 (1977) 511-514.

[159] Pfisterer A.B., Schmid B., Diversity-dependent production can decrease the stability of ecosystem functioning, Nature 416 (2002) $84-86$

[160] Piou D., Chandelier P., Morelet M., Sphaeropsis sapinea, un nouveau problème sanitaire des pins en France? Rev. For. Fr. 43 (1991) 203-213.

[161] Piou D., Delatour C., Marcais B., Hosts and distribution of Collybia fusipes in France and factors related to the disease's severity, For. Pathol. 32 (2002) 29-41.

[162] Popoola T.O.S., Fox R.T.V., Effect of water stress on infection by species of honey fungus (Armillaria mellea and A. gallica), Arbor. J. 27 (2003) 139-154

[163] Puritch G.S., Mullick D.B., Effect of water stress on the rate of non-suberized impervious tissue formation following wounding in Abies grandis, J. Exp. Bot. 26 (1975) 903-910.

[164] Ragazzi A., Moricca S., Dellavalle I., Interactions between Quercus spp. and Diplodia mutila under water stress conditions, Zeit. Pflanzenkrankh. Pflanzensch. 106 (1999) 495-500.

[165] Ragazzi A., Moricca S., Dellavalle I., Water stress and the development of cankers by Diplodia mutila on Quercus robur, J. Phytopathol. 147 (1999) 425-428.

[166] Ragazzi A., Morrica S., Turco E., Delavalle I., Dendroclimatic analysis of Quercus robur infected with Fusarium eumartii, Phytopathol. Mediterr. 41 (2002) 131-137.

[167] Rayner A.D.M., Water and the origins of decay in trees, in: Ayres P.G., Boddy L. (Eds.), Water, fungi and plants, Cambridge University Press, 1986, pp. 321-341. 
[168] Redfern D.B., The effect of wood moisture on infection of Sitka spruce stumps by basidiospores of Heterobasidion annosum, Eur. J. For. Pathol. 23 (1993) 218-235.

[169] Redfern D.B., Stenlid J., Spore dispersal and infection, in: Woodward S., Stenlid J., Karjalainen R., Hüttermann A. (Eds.), Heterobasidion annosum. Biology, Ecology, Impact and Control, CAB Int., Oxon, UK, 1998, pp. 105-124.

[170] Rizhsky L., Liang H., Mittler R., The combined effect of drought stress and heat shock on gene expression in tobacco, Plant Physiol. 130 (2002) 1143-1151.

[171] Rouault G., Candau J.N., Lieutier F., Nageleisen L.M., Martin J.C., Warzee N., Effects of drought and heat on forest insect populations in relation to the 2003 drought in Western Europe, Ann. Sci. For. 63 (2006) 611-622.

[172] San Martin González F., Rogers J.D., Biscogniauxia and Camillea in Mexico, Mycotaxon 47 (1993) 229-258.

[173] Schoeneweiss D.F., Predisposition, stress and plant disease, Ann. Rev. Phytopathol. 13 (1975) 193-211.

[174] Schoeneweiss D.F., Water stress as a predisposing factor in plant disease, in: Water Deficits and Plant Growth, Vol. V, Water and Plant Disease, 1978

[175] Schoeneweiss D.F., Role of environmental stress in diseases of woody plants, Plant Dis. 65 (1981) 308-314.

[176] Schoeneweiss D.F., Water stress predisposition to disease, an overview, in: Ayres P.G., Boddy L. (Eds.), Water, fungi and plants, Cambridge University Press, 1986, pp. 157-174.

[177] Shields W.J., Hobbs S.D., Soil nutrient levels and pH associated with Armillaria mellea on conifers in northern Idaho, Can. J. For. Res. 9 (1979) 45-48.

[178] Siang C.T., Yuan S.Z., Meng F.R., Jiang J.Q., Studies on the Diplodia shoot blight of Pinus sylvestris var. mongolica., J. NorthEastern Forestry Institute, China, 2 (1981) 1-10.

[179] Slippers B., Crous P.W., Denman S., Coutinho T.A., Wingfield B.D., Wingfield M.J., Combined multiple gene genealogies and phenotypic characters differentiate several species previously identified as Botryosphaeria dothidea, Mycologia 96 (2004) 83101.

[180] Smith H., Wingfield M.J., Petrini O., Botryosphaeria dothidea endophytic in Eucalyptus nitens in South Africa, For. Ecol. Manage. 89 (1996) 189-195.

[181] Smith H., Wingfield M.J., Wet J. de, Coutinho T.A., Genotypic diversity of Sphaeropsis sapinea from South Africa and Northern Sumatra, Plant Dis. 84 (2000) 139-142.

[182] Smith H., Wingfied M.J., Coutinho T.A., The role of latent Sphaeropsis sapinea infections in post-hail associated die-back of Pinus patula, For. Ecol. Manage. 164 (2002) 177-184.

[183] Solla A., Gil L., Influence of water stress on Dutch elm disease symptoms in Ulmus minor, Can. J. Bot. 80 (2002) 810-817.

[184] Stanosz G.R., Carlson J.C., Association of mortality of recently planted seedlings and established saplings in red pine plantations with Sphaeropsis collar rot, Plant Dis. 80 (1996) 750-753.

[185] Stanosz G.R., Smith D.R., Guthmiller M.A., Stanosz J.C., Persistence of Sphaeropsis sapinea on or in asymptomatic shoots of red and jack pines, Mycologia 89 (1997) 525-530.

[186] Stanosz G.R., Swart W.J., Smith D.R., RAPD marker and isozyme characterization of Sphaeropsis sapinea from diverse coniferous hosts and locations, Mycol. Res. 103 (1999) 1193-1202.

[187] Stanosz G.R., Blodgett J.T., Smith D.R., Kruger E.L., Water stress and Sphaeropsis sapinea as a latent pathogen of red pine seedlings, New Phytol. 149 (2001) 531-538.

[188] Sury R. von, Fluckiger W., Effects of air pollution and water stress on leaf blight and twig cankers of London planes (Platanus acerifolia (Ait.) Willd.) caused by Apiognomonia veneta (Sacc. \& Speg.) Hohn., New Phytol. 118 (1991) 397-405.
[189] Sutton B.C., The Coelomycetes. Fungi imperfecti with pycnidia, acervuli and stromata, CMI, Kew, England, 1980.

[190] Swart W.J., Wingfield M.J., Knox-Davis P.S., Conidial dispersal of Sphaeropsis sapinea in three climatic regions of South Africa, Plant Dis. 71 (1987) 1038-1040.

[191] Swart W.J., Wingfield M.J., Biology and control of Sphaeropsis sapinea on Pinus species in South Africa, Plant Dis. 75 (1991) 761-766.

[192] Swart W.J., Conradie E., Wingfield M.J., Venter W.B., Effects of water stress on the development of cambial lesions caused by Cryphonectria cubensis on Eucalyptus grandis, Plant Dis. 76 (1992) 744-746.

[193] Termorshuizen A.J., Arnolds E.J.M., Geographical distribution of the Armillaria species in the Netherlands in relation to soil type and hosts, Eur. J. For. Pathol. 24 (1994) 129-136.

[194] Tilman D., Reich P.B., Knops J., Wedin D., Mielke T., Lehman C., Diversity and productivity in a long-term grassland experiment, Science 294 (2001) 843-845.

[195] Tippett J.T., Crombie D.S., Hill T.C., Effect of phloem water relations on the growth of Phytophthora cinnamomi in Eucalyptus marginata, Phytopathology 77 (1987) 246-250.

[196] Torres J.J., El Hypoxylon mediterraneum (DeNot.) Mill. y su comportamiento en los encinares alcornocale nadaluces, Boletin Servicio Plagas 11 (1985) 185-191.

[197] Tregonning K.C., Fagg P.C., Seasonal rainfall and Eucalyptus dieback epidemics associated with Phytophthora cinnamomi in Gippsland, Victora, Austr. For. Res. 14 (1984) 219-234.

[198] Vallelian-Bindschedler L., Schweizer P., Mosinger E., Metraux J.P., Heat-induced resistance in barley to powdery mildew (Blumeria graminis f. sp. hordei) is associated with a burst of active oxygen species, Physiol. Mol. Plant Pathol. 52 (1998) 185199.

[199] Vannini A., Endophytes and oak decline in Southern Europe The role of Hypoxylon mediterraneum, 7th Int. Congr. of Plant Pathology, Invited papers abstracts - Vol. 1, 2.9.5S, 1998.

[200] Vannini A., Scarascia Mugnozza G., Water stress: a predisposing factor in the pathogenesis of Hypoxylon mediterraneum on Quercus cerris, Eur. J. For. Pathol. 21 (1991) 193-201.

[201] Vannini A., Valentini R., Influence of water relations on Quercus cerris-Hypoxylon mediterraneum interaction: a model of droughtinduced susceptibility to a weakness parasite, Tree Physiol. 14 (1994) 129-139.

[202] Vannini A., Biocca M., Paparatti B., Contributo alla conoscenza del ciclo biologico di Hypoxylon mediterraneum (De Not.) Mill. su Quercus cerris, Inf. Fitopat. LVI (1996) 53-55.

[203] Vannini A., Paganini R., Anselmi N., Factors affecting discharge and germination of ascospores of Hypoxylon mediterraneum (DeNot.) Mill., Eur. J. For. Pathol. 26 (1996) 12-24.

[204] Vannini A., Valentini R., Luisi N., Impact of drought and Hypoxylon mediterraneum on oak decline in the mediterranean region, Ann. Sci. For. 53 (1996) 753-760.

[205] Vivin P., Aussenac G., Levy G., Differences in drought resistance among 3 deciduous oak species grown in large boxes, Ann. Sci. For. 50 (1993) 221-233.

[206] Wahlstrom K.T., Barklund P., Spread of Armillaria spp. and Heterobasidion annosum in Norway spruce exposed to drought, irrigation and fertilization, Proc. of the 8th Int. IUFRO conf. on root and butt rot of forest trees, Wik, Sweden and Haikko, Finland, August 9-16 1993, Johansson M., Stenlid J. (Eds.), 1994, pp. 582591 .

[207] Wahlström K.T., Unestam T., Host stress and Armillaria infection in Scots pine bark, in: Wahlström K.T., Infection biology of Armillaria species: in vitro pectinolytic activity, infection strategy, field distribution and host responses, Swedish University of Agricultural Sciences, Depart. For. Mycol. Pathol. Uppsala, I, 1992, pp. 1-18. 
[208] Wan J., Dunning M., Bent A.F., Probing plant-pathogen interactions and downstream defense signalling using microarrays, Funct. Integr. Genomics 2 (2002) 259-273.

[209] Wang C.G., Blanchette R.A., Jackson W.A., Palmer M.A., Differences in conidial morphology among isolates of Sphaeropsis sapinea, Plant Dis. 69 (1985) 838-841.

[210] Wargo P.M., Consequences of environmental stress on oak: predisposition to pathogens, Ann. Sci. For. 53 (1996) 359-368.

[211] Wargo P.M., Harrington T.C., Host stress and susceptibility, in: Shaw C.G., Kile G.A. (Eds.), Armillaria root disease, Agriculture handbook 691, US Depart. Agric. For. Serv. 1991, pp. 88-101.

[212] Waterman A.M., Diplodia pinea, the cause of disease of hard pines, Phytopathology, 33 (1943) 1018-1031.

[213] Watkinson J.I., Sioson A.A., Vasquez-Robinet C., Shukla M., Kumar D., Ellis M., Heath L.S., Ramakrishnan N., Chevone B., Watson L.T., van Zyl L., Egertdoterr U., Sederoff R.R., Grene R., Photosynthetic acclimation is reflected in specific patterns of gene expression in drought-stressed loblolly pine, Plant Physiol. 133 (2003) 1702-1716.

[214] Wet J. de, Wingfield M.J., Coutinho T., Wingfield B.D., Characterisation of the ' $\mathrm{C}$ ' morphotype of the pine pathogen Sphaeropsis sapinea, For. Ecol. Manage. 161 (2002) 181-188.

[215] Wet J. de, Burgess T., Slippers B., Preisig O., Wingfield B.D., Wingfield M.J., Multiple gene genealogies and microsatellite markers reflect relationships between morphotypes of Sphaeropsis sapinea and distinguish a new species of Diplodia, Mycol. Res. 107 (2003) 557-566.
[216] Whitney R.D., Site variation of Armillaria mellea in three Ontario conifers, in: Kile G.A. (Ed.), Proc. 6th Int. Conf. on root and butt rots, Melbourne, Victoria, and Gympie, Queensland, Australia, 1984, pp. 122-130.

[217] Wiensczyk A.M., Dumas M.T., Irwin R.N., Predicting Armillaria ostoyae infection levels in black spruce plantations as a function of environmental factors, Can. J. For. Res. 27 (1997) 1630-1634.

[218] Wingfield M.J., Wingfield B.D., Coutinho T.A., Wet J. de, Slippers B., Fungal diseases of exotic plantation pines: a southern hemisphere perspective, in: Sustainability of pine forests in relation to pine wilt and decline, Proc. Int. Symp., Tokyo, Japan, 27-28 October 1998, 1999, pp. 322-329.

[219] Xiong L., Yang Y., Disease resistance and abiotic stress tolerance in rice are inversely modulated by an abscissic acid-inducible mitogen-activated protein kinase, Plant Cell 15 (2003) 745-759.

[220] Xiong L., Schumaker K.S., Zhu J.K., Cell signaling during cold, drought, and salt stress, Plant Cell 14 (2002) s165-s183.

[221] Zhang P.G., Sutton J.C., High temperature, darkness, and drought predispose black spruce seedlings to gray mold, Can. J. Bot. 72 (1994) 135-142.

[222] Zhang S., Klessig D.F., MAPK cascades in plant defense signalling, Trends Plant Sci. 6 (2001) 520-527.

[223] Zhou S., Stanosz G.R., Primers for amplification of mt SSU rDNA and a phylogenetic study of Botryosphaeria and associated anamorphic fungi, Mycol. Res. 105 (2001) 1033-1044.

[224] Zhu J-K., Salt and drought stress signal transduction in plants, Annu. Rev. Plant Biol. 53 (2002) 247-273. 